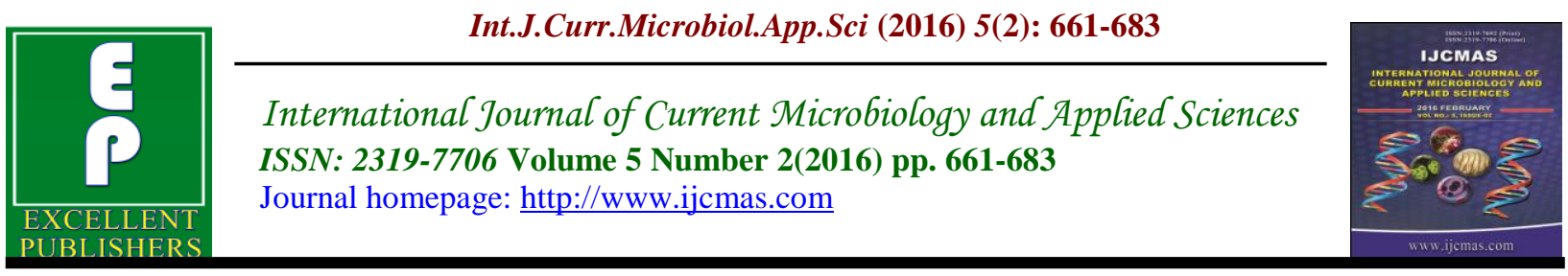

Original Research Article

doi: http://dx.doi.org/10.20546/ijcmas.2016.502.074

\title{
Amazing Multiple Function Properties of Plant Growth Promoting Rhizobacteria in the Rhizosphere Soil
}

\author{
K. Sureshbabu ${ }^{*}$, N. Amaresan ${ }^{2}$ and K. Kumar ${ }^{3}$ \\ ${ }^{1}$ Indian Agricultural Research Institute, Regional Station, Nilgiris, India \\ ${ }^{2}$ C.G. Bhakta Institute of Biotechnology, Uka Tarsadia University, \\ Bardoli, Surat 394 350, Gujarat, India \\ ${ }^{3}$ Division of Field Crops, Central Agricultural Research Institute, Port Blair, India \\ *Corresponding author
}

\begin{abstract}
A B S T R A C T
Keywords

Plant growth promoting rhizobacteria, Siderophore, Phosphate solubilizing bacteria, Indole acetic acid.

\section{Article Info}

Accepted:

26 January 2016

Available Online:

10, February 2016

Plant-bacterial interactions in the rhizosphere are the determinants of plant health and soil fertility. These are associated with the rhizosphere, which is an important soil ecological environment for plant-microbe interactions. Plant growth promoting rhizobacteria (PGPR) are considered to promote plant growth directly or indirectly. PGPR can exhibit a variety of characteristics responsible for influencing plant growth. The exact mechanisms by which PGPR promote plant growth are not fully understood, but are thought to include (i) the ability to produce or change the concentration of plant growth regulators like indoleacetic acid, gibberellic acid, cytokinins and ethylene (Arshad and Frankenberger, 1993; Glick, 1995), (ii) asymbiotic N2 fixation (Boddey and Dobereiner, 1995), (iii) antagonism against phytopathogenic microorganisms by production of siderophores (Scher and Baker, 1982), antibiotics (Shanahan et al., 1992) and cyanide (Flaishman et al., 1996), (iv) solubilization of mineral phosphates and other nutrients (De-Freitas et al., 1997; Gaur, 1990). Another mechanism by which PGPR can inhibit fungal cell wall degrading enzymes, e.g., chitinase and ß-1,3-glucanase.Biological control of soilborne plant pathogens and the synthesis of antibiotics have also been reported in several bacterial species. This review begins with describing how the bacteria help plant directly and indirecty to producing hydohytic enzyme, hormone, cyanide and sidrophore.
\end{abstract}

\section{Introduction}

The concept of plant growth promoting rhizobacteria is now well established, both for growth promotion and biocontrol. Plant growth promoting rhizobacteria (PGPR) were first defined by Kloepper and Schroth (1978) to describe soil bacteria that colonize the roots of plants following inoculation onto seed and they enhance plant growth The ineffectiveness of PGPR in the field has often attributed to their inability to colonize plant roots (Lugtenberg, et al., 2001). Plant growth-promoting rhizobacteria (PGPR) colonizing the surface or inner part of roots play an important positive role that directly 
or indirectly influences plant growth and development (Gerhardt, K. E et al, 2009; Glick, B. R., 1999).

The mechanism by which PGPR increases crop performance is not well understood. There are several PGPR inoculants currently commercialized that seem to promote growth through at least one mechanism; suppression of plant disease (termed "Bioprotectants"), phytohormone production (termed "Biostimulants"), or improved nutrient acquisition (termed "Biofertilizers").

Biofertilizer is a material containing microorganisms added to a soil to directly or indirectly make certain essential elements available to plants for their nutrition through synthesis of growth promoting substances or by enhancing the decomposition of plant residues. Various sources of biofertilizers include nitrogen fixers, phytostimulators, phosphate solubilizing bacteria, plant growth promoting rhizobacteria etc. Considerable progress has been made over the past two decades in evaluation of these technologies and development of application methods (Afzal and Asghari, 2008).

Microorganisms are important for agriculture in order to promote the circulation of plant nutrients and reduce the need of chemical fertilisers. The use of fertilizers, including chemical fertilizers and manures, to enhance soil fertility and crop productivity has often negatively affected the complex system of the biogeochemical cycles (Perrott et al., 1992; Steinshamn et al., 2004). Fertilizer use has caused leaching and run-off of nutrients, especially Nitrogen (N) and Phosphorus (P), leading to environmental degradation (Tilman, 1998; Gyaneshwar et al., 2002). Plant growth promoting rhizobacteria (PGPR) accounts for about $2-5 \%$ of total the rhizobacteria involved in plant growth promotion (Antoun and Kloepper, 2001).

\section{Plant Growth-Promoting Rhizobacteria (PGPR)}

Plant growth-promoting rhizobacteria (PGPR) offer an environment-friendly means for increasing productivity and sustainability in agriculture. Many bacterial species, mostly associated with plant rhizosphere, have been tested and found to be beneficial for plant growth, yield, and crop quality. They have been called "plant growth promoting rhizobacteria (PGPR)". PGPR are also termed as plant health promoting rhizobacteria (PHPR) or nodule promoting rhizobacteria (NPR) and are associated with the rhizosphere, which is an important soil ecological environment for plant-microbe interactions (Burr and Caesar, 1984). Generally, PGPR function in three different ways (Glick, 1995, 2001): synthesizing particular compounds for the plants (Dobbelaere et al., 2003; Zahir et al., 2004), facilitating the uptake of certain nutrients from the soil (Lucas et al., 2004; Çakmakçi et al., 2006), and lessening or preventing the plants from diseases (Jetiyanon and Kloepper, 2002; Raj et al., 2003; Guo et al., 2004; Saravanakumar et al., 2008). These bacterial species are in the genera Serratia, Pseudomonas, Burkholderia, Agrobacterium, Erwinia, Xanthomonas, Azospirillum, Bacillus, Enterobacter, Rhizobium, Alcanigenes, Arthrobacter, Acetobacter, Acinetobacter, Achromobacter, Aerobacter, Artrobacter, Azotobacter, Clostridium, Klebsiellla, Micrococcus, Rhodobacter, Rhodospirrilumand, Flavobacterium (Rodriguez and Fraga, 1999; Bloemberg and Lugtenberg, 2001; Esitken et al., 2003).

The common traits of growth promotion includes production or changes in the 
concentration of plant hormones such as auxin, gibberellins, cytokinins and ethylene. Indole acetic acid (IAA) is one of the most physiologically active auxin. IAA released as secondary metabolite because of rich supplies of substrates exuded from the roots (Strzelczyk and Pokojska, 1984; Ahmad et al., 2005) Microbial biosynthesis of IAA in soil is enhanced by tryptophan secreted from roots or decaying cells (Benezri et al., 1998).

Phosphates and other nutrient are also solubilized by PGPR strains to increase the availability of ' $\mathrm{P}$ ' for plants in soil with large amount of precipitated phosphates (Goldstein, 1986) and nitrogen fixation. These bacteria are also capable to suppress thegrowth of deleterious microorganisms by production of siderophores, $\beta \quad 1,3$ glucanases, chitinases and antibiotics (Cattelan et al., 1999). Siderophore producing bacteria promote plant growth indirectly by sequestrating the limited iron in the rhizosphere and reduce the availability for growth of phytopathogens (Alexander and zeeberi, 1991). Plant growth benefits due to the addition of PGPR include increases in germination rate, root growth, yield, leaf area, chlorophyll content, nitrogen content, protein content, tolerance to drought, shoot and root weight, and delayed leaf senescence (Dobbelaere et al., 2003; Cakmakc1, 2005a, 2005b).

PGPR have been demonstrated to increase growth and productivity of many commercial crops including rice (Ashrafuzzaman et al., 2009), wheat (Khalid et al., 2004, Cakmakc1 et al., 2007), cucumber (Maleki et al., 2010), maize (Sandhya et al., 2010), cotton (Anjum et al., 2007), black pepper (Dastager et al., 2010), and Bnana (Mia et al., 2010) canola (de Freitas et al., 1997), sugar beet (Cakmakcı et al., 1999), sugarcane (Sundara et al., 2002), conifer species (Bent et al., 2002).

Significant increases in growth and yield of agronomically important crops in response to inoculation with PGPR have been reported many times (Kloepper et al., 1980; Chen et al., 1994; Zhang et al., 1996; Amara and Dahdoh, 1997; Chanway, 1998; Pan et al., 1999; Bin et al., 2000; Biswas et al., 2000; Asghar et al., 2002; Vessey, 2003; Silva et al., 2006). PGPR beneficial effects have been exploited in many areas including biofertilizers, microbial rhizoremediation and biopesticides (Adesemoye et al., 2008)

\section{Indirect Mechanisms}

Indirect mechanisms used by PGPR include antibiotic protection against pathogenic bacteria, reduction of iron available to phytopathogens in the rhizosphere, synthesis of cell wall degrading enzymes, such as $\beta-1$, 3-glucanases, cellulases, proteases and chitinases are involved in the antagonistic activity of some biological control agents against phytopathogenic fungi (Chernin et al., 1995; Dunn et al., 1997; Ordentlich et al., 1988; Harman et al., 1993). Indirect growth promotion occurs through the elimination of pathogens by the production of cyanide (Owen and Zlor, 2001). PGPB have also been reported to be able to produce enzymes such as, lipase, by which they can lysis the cells of fungal pathogens (van Loon et al., 2006). Dunne and collaborators (2000) showed that overproduction of extracellular protease in the mutant strains of Stenotrophomonas maltophilia W81 resulted in improved biocontrol of Pythium ultimum. PGPR also promote plant growth by suppressing growth of plant pathogens and deleterious rhizosphere microorganisms, thus freeing the plant from growth limitations that would have resulted because of the presence of these microorganisms 
(Kloepper, 1992; Schippers et al., 1987).These indirect mechanisms, such as suppression of harmful microorganisms and induced systemic resistance (ISR), are normally recognized as having a role in biological control (Kloepper, 1992; Dobbelaere et al., 2003).

\section{Direct Mechanisms}

Direct promotion of growth by PGPR occurs when the rhizobacteria produce metabolites that promote plant growth such as auxins (Asghar et al., 2002), cytokinins (Arkhipova et al., 2005) and gibberellins (Gutierrez Manero et al., 2001; Joo et al., 2004) as well as through the solubilization of phosphate minerals (Freitas et al., 1997).

Plant growth promoting rhizobacteria and endophytes accelerates phytoremediation of metalliferous soils though modulation of (a) plant growth promoting parameters, (b) by providing plants with nutrients, and (c) controlling disease through the production of antifungal metabolites. Abbreviations: indole-3-acetic acid (IAA), indole-3acetamide (IAM) pathway, indole-3pyruvate (IPyA) pathway, methionine-Sadenosylmethionine (SAM), 1aminocyclopropane-1-carboxylate (ACC), 1-aminocyclopropane-1-carboxylate synthase (ACS), phosphatase (Ptase), ammonia (NH3), hydrogen cyanide (HCN). (Maa et al., 2011)

Siderophore (Greek- literally means iron carrier)

Iron $(\mathrm{Fe} 3+)$ is biologically important being a constituent of cytochrome and others heme or non-heme proteins and also a co-factor in various enzymes. When aerobic or facultative anaerobic microorganisms grow in an iron-deficient environment, they synthesize $\mathrm{Fe} 3+$ ion specific chelating agents called siderophores (Goto, 1990). Siderophores are low molecular weight (500-1000 Da) compounds produced by fungi and bacteria, which bind with $\mathrm{Fe} 3+$ ions to be transported into the cell (Neilands, 1989). Based on their structure, the majority of the known siderophores have been grouped either as catecholates, produced only by bacteria, or as hydroxymates which are produced by fungi and bacteria.

\section{Siderophore as Biocontrol}

Siderophores, low molecular weight compounds with high iron affinity, are produced by some microorganisms (also by most biocontrol agents) to solubilize and competitively acquire ferric ion under ironlimiting conditions, thereby making iron unavailable to other soil microorganisms which cannot grow for lack of it (Haas et al., 2005; Loper et al., 1997).The bacterium that originally synthesized the siderophores takes up the iron siderophore complex by using a receptor that is specific to the complex and is located in the outer cell membrane. Suppression of soil borne plant pathogens by siderophore producing Pseudomonads has been reported in some instances (Buysens et al., 1996; Loper, 1988; Weger et al., 1988).

Consequently, to survive in such environments, organisms secrete ironbinding ligands (siderophores) that can bind ferric iron and make it available to the host microorganisms. Although various bacterial siderophores differ in their abilities to sequester iron, in general, they deprive pathogenic fungi of this essential element since the fungal siderophores have lower affinity (Loper and Henkels, 1999; O’Sullivan and O’Gara, 1992).

The production of siderophores by the biocontrol agents in quantities sufficient may to limited $\mathrm{Fe} 3+$ availability to the 
pathogen (Glick and Bashan, 1997) and is possible lead to induction of host resistance against the pathogen (Meziane et al., 2005). Siderophore production is very common among Pseudomonads (O’Sullivan and O’Gara, 1992) Frankia (Boyer et al., 1999) and Streptomyces sp. (Loper and Buyer, 1991). Escherichia coli, Salmonella typhimurium (Martinez et al., 1990), Actinobacillus pleuropneumoniae (Diarra et al., 1996), Streptomyces sp. (Imbert et al., 1995), and Arthrobacter flavescens (Winkelmann, 1991 have also been shown to produce iron-chelating compounds. Siderophores are not only used in the process of plants acquiring iron and other metals, they also are found on bacteria in the body on cells and in some cases the siderophores rob our own blood cells of iron. Escherichia coli strains have been used in CAS assays to demonstrate the production of siderophores (Schwyn and Neilands, 1987). Production of siderophore and antifungal activity were simultaneously exhibited by free-living rhizospheric isolates of Azotobacter (16.22\%), fluorescent Pseudomonas (11.11\%) and Bacillus (10\%) (Ahmad et al., 2008).

Under metal-limiting conditions, the bacterium $A$. vinelandii secretes metalscavenging compounds (siderophores; S) (1). These siderophores scavenge the metals molybdenum and vanadium from unavailable complexes with clay, soil organic matter or other elements (2). The siderophores compete with siderophores produced by other organisms such as fungi for these metals (3).

The bacterium or plant roots readily take up the siderophore-metal complexes (4). Within the bacterium, the metal is incorporated into the enzyme nitrogenase (5), to allow the fixation of atmospheric nitrogen (N2) that would otherwise be unusable to the bacterium. (Alexander and Zuberer, 1991).

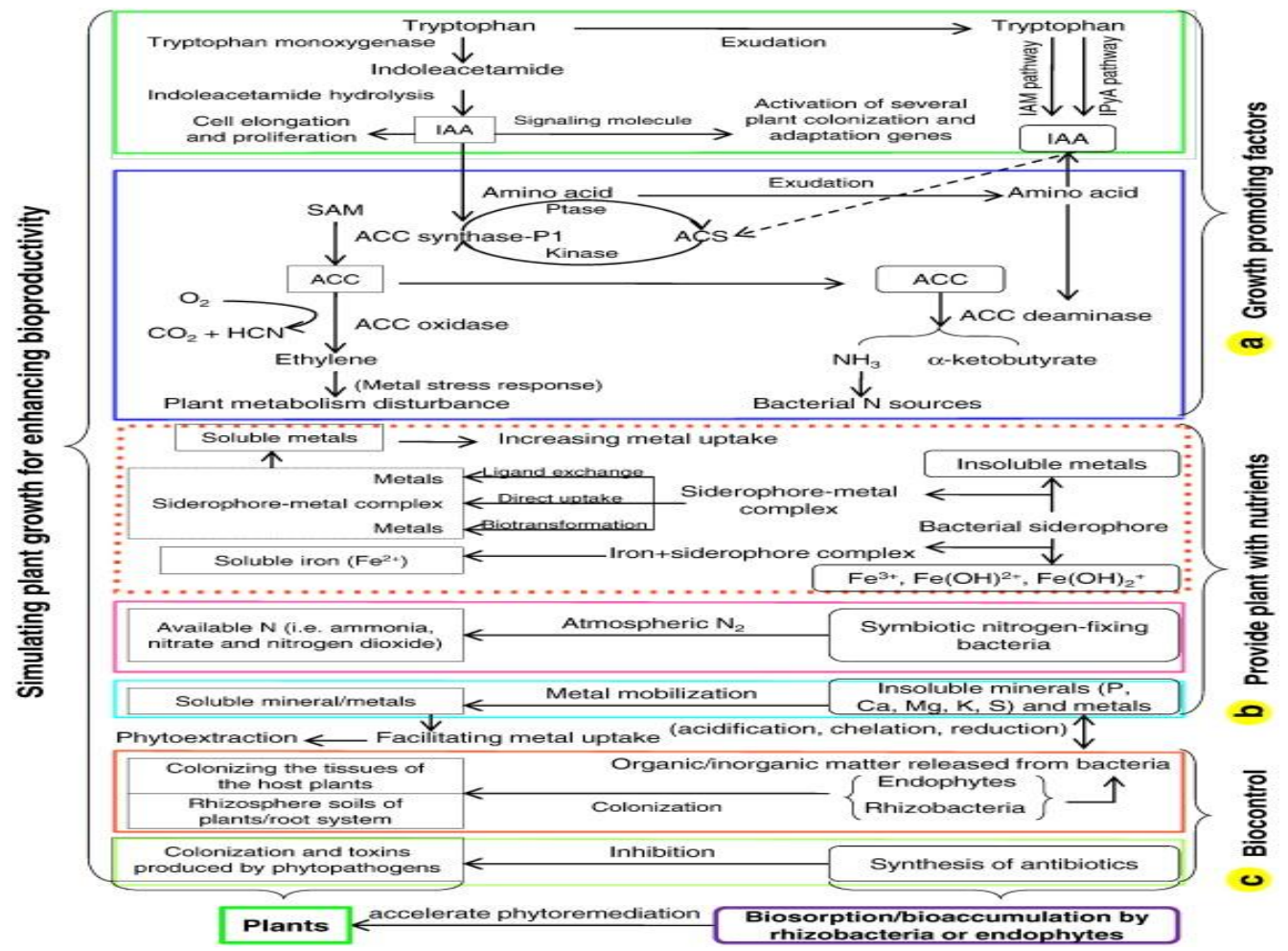




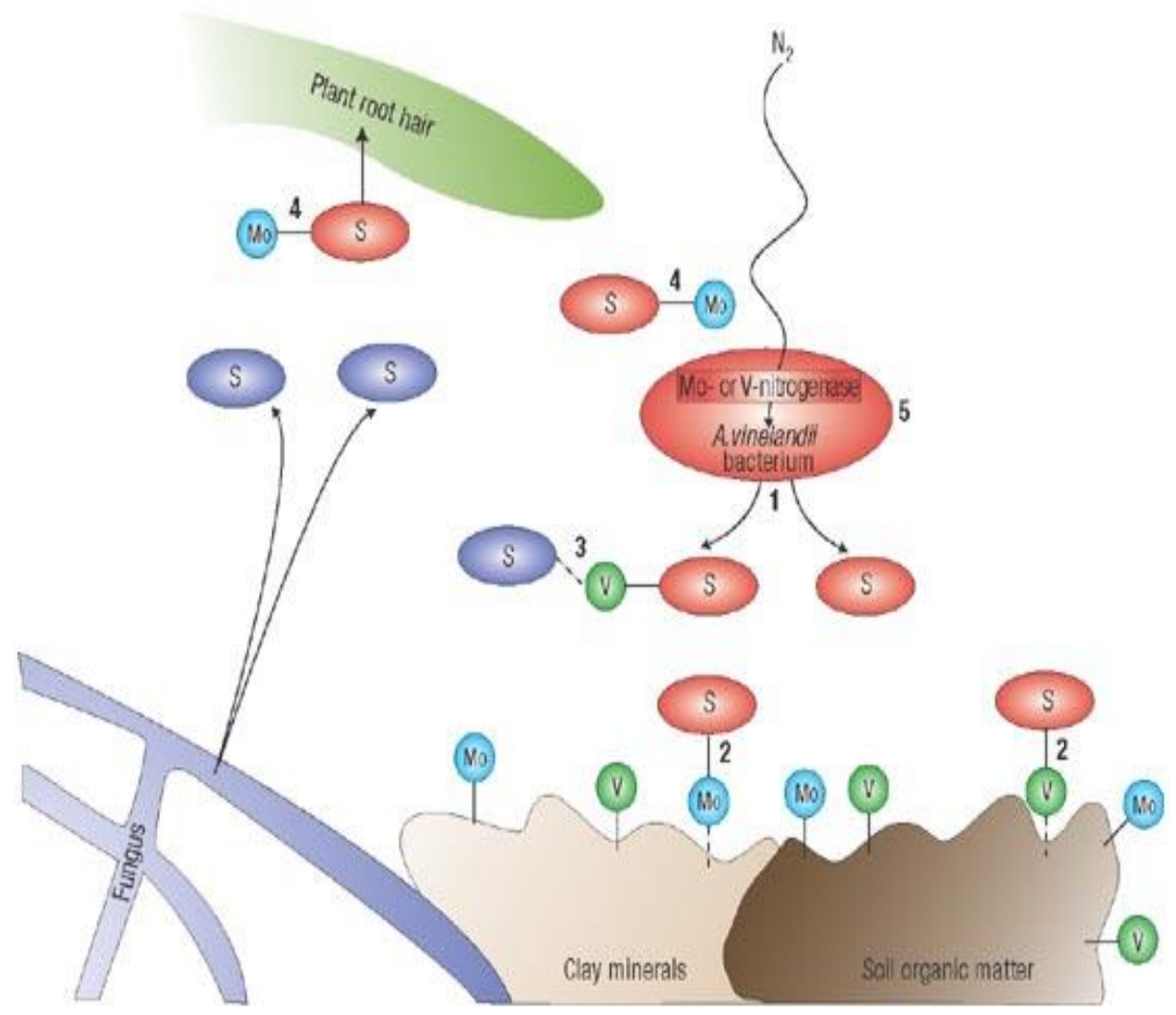

\section{Siderophore as Micro nutrient Provider}

Plants are able to use bacterial iron sidrophore complexes as a source of iron from the soil (Neilands, 1993; Wang et al, 1993; Riquelme, 1996). The role of siderophores is to scavenge iron from the environment and make the mineral available to the cell (Neilands, 1995).

Poaceae (grasses) including agriculturally important species such as barley and wheat are able to efficiently sequester iron by releasing phytosiderophores via their root into the surrounding soil rhizosphere (Kraemer et al., 2001). Thus, these plants are unable to uptake sufficient amounts of iron. Further, heavy metals that are accumulated in excess in plant tissues can cause changes in various vital growth processes and have negative effects on iron nutrition. Under such conditions, the siderophore producing rhizosphere bacteria might offer a biological rescue system that is capable of chelating $\mathrm{Fe} 3+$ and making it available to plant roots (Fig. 2). The roots could then take up iron from siderophoresFe complexes possibly via the mechanisms such as chelate degradation and release of iron, the direct uptake of siderophore-Fe complexes, and/or a ligand exchange reaction (Rajkumar et al., 2010).

Several examples of increased $\mathrm{Fe}^{2+}$ uptake in plants with concurrent stimulation of plant growth as a result of PGPB inoculations have been reported (Burd et al., 2000; Barzanti et al., 2007; CarrilloCastañeda et al., 2003). Siderophores also promote bacterial IAA synthesis by reducing the detrimental effects of heavy metals through chelation reaction (Dimkpa et al., 2008).

Chemical compounds produced by microorganisms in the rhizosphere can also increase the availability and uptake of iron. Plants such as oats are able to assimilate iron 
via these microbial siderophores. It has been demonstrated that plants are able to use the hydroxamate-type siderophores ferrichrome, rodotorulic acid and ferrioxamine $\mathrm{B}$; the catechol-type siderophores, agrobactin; and the mixed ligand catechol-hydroxamatehydroxy acid siderophores biosynthesized by saprophytic root-colonizing bacteria. All of these compounds are produced by rhizospheric bacterial strains, which have simple nutritional requirements, and are found in nature in soils, foliage, fresh water, sediments, and seawater (Carrillo-Castañeda et al., 2002). Several studies have demonstrated that production of siderophore by PGPR was most effective in controlling the plant root pathogens (Mullen, 1998; Diaz et al., 2002; and Dey et al., 2004). B. subtilis, $B$. amyloliquefaciens, and $B$. pumilus have a background of being biological control agents against diverse soil pathogens (El-Hassan and Gowen, 2006; Liu et al., 2008; Szczech and Shoda, 2006; Yu et al., 2002;).

Siderophore production enables bacteria to compete with pathogens by removing iron from the environment $\left(\mathrm{O}^{\prime}\right.$ Sullivan and O'Gara 1992; Persello-Cartieaux et al. 2003). Although various bacterial siderophores differ in their abilities to sequester iron, in general, they deprive pathogenic fungi of this essential element since the fungal siderophores have lower affinity (Loper, and Henkels. 1999; O'Sullivan, and Gara. 1992). E. coli isolated and characterized from endorhizosphere of sugarcane (Saccharum sp.) and rye grass (Lolium perenne) is found to produce maximum siderophores and thus is found to help in the growth of the plants (Gangwar, et al 2009).

\section{Phosphate Solubilizing Bacteria (PSB)}

Phosphorus is second only to nitrogen in mineral nutrients most commonly limiting the growth of terrestrial plants. Phosphorus (P) is one of the major essential macronutrients for plants and is applied to soil in the form of phosphatic fertilizers.

However, a large portion of soluble inorganic phosphate applied to the soil as chemical fertilizer is immobilized rapidly and becomes unavailable to plants (Goldstein, 1986) Phosphate solubilizing bacteria (PSB) are the group of common PGPR in rhizosphere. Secretion of organic acids and phosphatases to solubilize insoluble phosphate to soluble forms are common in this group (Kim et al., 1998).

Although several phosphate solubilizing bacteria occur in soil, their numbers are not adequate to compete with other bacteria commonly established in the rhizosphere (Glick et al., 1995) Moreover, the population of inorganic P-solubilizing microorganism is very low, less than 102cfu $\mathrm{g}$-1 of soil. Therefore the number of PSM is more important in the rhizosphere than in non -rhizosphere soil (Kucey et al., 1989). Microorganisms are involved in a range of processes that affect the transformation of soil $\mathrm{P}$ and are thus an integral part of the soil P cycle..

In particular, soil microorganisms are effective in releasing $\mathrm{P}$ from inorganic and organic pools of total soil $\mathrm{P}$ through solubilization and mineralization (Hilda and Fraga, 1999). Currently, the main purpose in managing soil phosphorus is to optimize crop production and minimize P loss from soils. Recently, phosphate solubilizing microorganisms have attracted the attention of agriculturists as soil inoculums to improve the plant growth and yield (Young, 1994; Young et al., 1998; Goldstein et al., 1999; Fasim et al., 2002). 
Phosphate-solubilizing bacteria are common in rhizospheres (Nautiyal et al., 2000; Vazquez et al., 2000b). Bacterial strains belonging to genera Pseudomonas, Bacillus, Rhizobium, Burkholderia, Achromobacter, Agrobacterium, Microccocus, Aerobacter, Flavobacterium and Erwinia have the ability to solubilize insoluble inorganic phosphate (mineral phosphate) compounds such as tricalcium phosphate, dicalcium phosphate, hydroxyl apatite and rock phosphate (Goldstein, 1986; Rodríguez and Fraga, 1999; Rodríguez et al., 2006). Strains from genera Pseudomonas, Bacillus and Rhizobium are among the most powerful phosphate solubilizers, while tricalcium phosphate and hydroxyl apatite seem to be more degradable substrates than rock phosphate (Arora and Gaur, 1979; Banerjee et al., 2006; Halder and Chakrabarty, 1993; Illmer and Schinner, 1992; Rodríguez and Fraga, 1999;).

Four strains, namely Arthrobacter ureafaciens, Phyllobacterium myrsinacearum, Rhodococcus erythropolis and Delftia sp. have been reported for the first time by (Chen et al., 2006) as phosphate-solubilizing bacteria (PSB) after confirming their capacity to solubilize considerable amounts of tricalcium phosphate in the medium by secreting organic acids. Bacterial strains Azotobacter vinelandii and Bacillus cereus when tested in vitro are found to solubilise Phosphate and thus help in the growth of plant (Husen, 2003). Bacillus megaterium from tea rhizosphere is able to solubilize phosphate and thus it helps in the plant growth promotion (Chakraborty, 2006). Solubilisation of insoluble phosphorous compounds in the rhizosphere by microorganisms is another important means of achieving plant growth promotion (Gull et al., 2004).The most efficient Phosphate Solubilising Microorganisms belong to genera Bacillus, Rhizobium and
Pseudomonas amongst bacteria, and Aspergillus and Penicillium amongst fungi. Within rhizobia, two species nodulating chickpea, Mesorhizobium ciceri and Mesorhizobium mediterraneum, are known as good phosphate solubilizers (Rivas, 2006).

\section{Hydrolytic Enzymes}

A variety of mechanisms have been reported to contribute to the biocontrol activity of microbes and it is, for example, known that cell wall degrading enzymes, such as $\beta-1,3-$ glucanases, cellulases, proteases and chitinases are involved in the antagonistic activity of some biological control agents against phytopathogenic fungi (Chernin et al., 1995; Dunn et al., 1997; Harman et al., 1993; Ordentlich et al., 1988).

Bacterial strains that produce different hydrolytic enzymes such protease, lipase, pectinase, amylase also inhibited the growth of pathogenic fungi $F$. culmorum and $F$. oxysporum. Nielson and Sorensen (1999) demonstrated that $P$. fluorescens antagonistic to $R$. solani and Pythium ultimum, and produced lytic enzymes. Understanding the mode of action of biocontrol agents is a prerequisite for: (i) developing rational procedures in order to select more effective antagonistic microbial strains, (ii) developing appropriate production and formulation methods that enhance biocontrol activity, and (iii) fulfilling some requirements of the toxicological and registration packages needed for commercial development ( Jijakli and Lepoivre, 1998).

Biological control of plant diseases can be attained through reduction of inoculum quantity or disease causing capacity of a pathogen with use of one or more organisms except man (Cook and Baker, 1983). A microorganism can exert antagonism 
towards a plant pathogen directly by producing substances acting directly on one or more stages of the life cycle of the pathogen (Cook and Baker, 1983) or indirectly by activating mechanisms of host resistance towards the pathogen (Van Loon et al., 1998). The growth inhibition noticed in the volatile compound assay may be attributed to cyanogenesis from glycine, resulting in the production of $\mathrm{HCN}$, which is volatile in nature and plays a key role in the inhibition of phytopathogenic fungi namely Sclerotium rolfsii, Rhizoctonia solani and Pythium sp. under in vitro conditions (Bakker and Schipper, 1987).

\section{Indole Acetic Acid}

Bacteria belonging to the genera Azospirillum, Pseudomonas, Xanthomonas, and Rhizobium as well as Alcaligenes faecalis, Enterobacter cloacae, Acetobacter diazotrophicus and radyrhizobium japonicum have been shown to produce auxins which help in stimulating plant growth (Patten and Glick, 1996). IAA is the most common and best characterized phytohormone. It has been estimated that $80 \%$ of bacteria isolated from the rhizosphere can produce plant growth regulator IAA (Patten and Glick, 1996). Indole acetic acid (IAA) is one of the most physiologically active auxins. Auxins are produced by plants (Arshad and Frankenberger, 1991) and several microorganisms including bacteria (Barea et al., 1976) and fungi (Dvornikova et al., 1970).

Indole-3-acetic acid (IAA) is a common product of L-tryptophan metabolism by several microorganisms including PGPR (Frankenberger and Brunner, 1983; Lynch, 1985). Microorganisms inhabiting rhizospheres of various plants are likely to synthesize and release auxin as secondary metabolites because of the rich supplies of substrates exuded from the roots compared with non rhizospheric soils (Kampert et al., 1975; Strzelczyk and Pokojska-Burdziej, 1984). Plant morphogenic effects may also be a result of different ratios of plant hormones produced by roots as well as by rhizosphere bacteria (Muller et al., 1989).

IAA is the main auxin in plants, controlling many important physiological processes including cell enlargement and division, tissue differentiation, and responses to light and gravity. Bacterial IAA producers (BIPs) have the potential to interfere with any of these processes by input of IAA into the plant's auxin pool. The consequence for the plant is usually a function of the amount of IAA that is produced. A root, for instance, is one of the plant's organs that is, most sensitive to fluctuations in IAA and its response to increasing amounts of exogenous IAA extends from elongation of the primary root, formation of lateral and adventitious roots, (Finnie and Van Staden, 1985). It is now generally agreed that indole-3-acetic acid (IAA) is the major and most abundant auxin in plants.

IAA plays a key role in the regulation of plant growth and development (Moore, 1989; Luthen et al., 1999; Davies, 1995). Over the last few years significant progress has been made in understanding the IAAinduced signal transduction pathway (Shahab and Ahmed, 2008; Venis and Napier, 1991). Although other auxins, such as indole-3-acetic acid) indole 3 butyiic acid (IBA) and phenyl acetic acid (PAA) have also been identified in plants (Normanly, 1997) little is known about their physiological function. It is presumed that PGPB producing plant growth regulators play a critical role in plant growth promotion. Several studies have demonstrated the potential of rhizobacteria to synthesis auxins in vitro (Arshad and 
Frankenberger, 1993; and Benizri et al., 1998). Asghar et al., (2002) and Khalid et al., (2004) reported that addition of Ltryptophan (L-TRP) as an auxin precursor substantially increased auxin production.

The tryptophan increases the production of IAA in Bacillus amyloliquefaciens FZB42 (Idris et al., 2007). Tien et al. (1979) showed that Azospirillum is able to produce auxins when exposed to tryptophan. Karnwal (2009) tested Fluorescent Pseudomonas isolates for their ability to produce indole acetic acid in pure culture in the absence and presence of L-tryptophan and found that for both strains, indole production increased with increases in tryptophan concentration. Yasari and Patwardhan (2007) reported that application of Azotobacter and Azospirillum strains increased canola yield $(21.17 \%)$, pod per plant $(16.05 \%)$, number of branches (11.78\%) and weight of 1000grain (2.92\%).

\section{Hydrogen Cyanide}

The HCN production is found to be a common trait of Pseudomonas (88.89\%) and Bacillus (50\%) in the rhizospheric soil and plant root nodules (Ahmad et al., 2008; Charest et al., 2005).Cyanide is a secondary metabolite produced by gram negative bacteria (Askeland and Morrison, 1983). Hydrogen cyanide $(\mathrm{HCN})$ and $\mathrm{CO}_{2}$ are formed from glycine and catalyzed by $\mathrm{HCN}$ synthase (Castric, 1994).

HCN productions by strains of Pseudomonas suppress diseases while mutant strain defective in synthesis of $\mathrm{HCN}$ lost the ability to protect plants from diseases (Voisard et al., 1989; Sacherer et al., 1994). Hydrogen cyanide ( $\mathrm{HCN})$ has been demonstrated in a small number of bacterial species, such as Pseudomonas aeruginosa, Pseudomon asuorescens and Chromobacterium violaceum (Askeland and
Morrison, 1983; Castric, 1975; Knowles and Bunch, 1986).

Ecological role for bacterial cyanogenesis has been discovered in the case of the rootcolonizing and plant-beneficial $P$. fuorescens strain CHAO (Voisard et al., 1989), which protects several plants from fungal root diseases (Voisard et al., 1994; Schnider et al., 1995). HCN production by strain CHA0 accounts for part of the strain's biocontrol capacity, for example the suppression of tobacco black root rot caused by Thielaviopsis basicola (Laville et al., 1998; Voisard et al., 1989). Iron sufficiency is important for both $\mathrm{HCN}$ production and disease suppression (Keel et al., 1989; Voisard et al., 1989).

\section{PGPR as Biocontrol}

Fungicides were the essential trial as seed treatment for controlling damping-off and root rot diseases for a long time. However, fungicidal treatments cause hazards to human health and increase environmental pollution. Therefore there are needed to alternative fungicidal. Pesticides and fertilizers cause damage to the environment and effect human health (Perkins and Patterson, 1997). As a consequence, there is a trend toward finding ways to minimize the use of fungicides (Maas and Galletta, 1997) seed treatments.

Biological control of crops diseases and pests using microbial inoculants is being increasingly recognized as a viable, ecofriendly alternative that limits the massive use of synthetic chemical pesticides (Charan et al., 2011). Plant-associated bacteria can be used directly for biological control of soil borne plant pathogens or indirectly for the productions of active substances (e.g., antibiotics, hydrolytic enzymes, osmoprotective substances (Berg, 2002). 
The antagonistic mechanisms towards fungal pathogens in vitro include their glucanolytic; chitinolytic, cellulolytic, proteolytic and pectinolytic activity (Berg, 2003).

The use of biocontrol agents (Elad and Shtienberg, 1996) and alternative treatments (e.g., cultural practices, cover crops, and organic amendments) are perceived to be less harmful than conventional fungicides and may be an alternative in controlling plant diseases (Cutler and Hill, 1994). Numerous researches have been focused on searching and selecting antagonist microorganisms on diverse soil pathogens. Among the most used are bacteria's like Bacillus, Pseudomonas, and Streptomyces, fungi of the Trichoderma, Penicillium, Gliocladium, Aspergillus, Rhizopus genera. These microorganisms, natural inhabitants of diverse substrates, in laboratory tests (in vitro) as well as in the greenhouse and field, have demonstrated antagonistic activity on a wide ranging group of pathogens such as Sclerotium rolfsii, S. cepivorum, Rhizoctonia solani, Pythium ultimum, Phytophthora parasitica, and M. phaseolina (Adekunle et al., 2001; Bell et al., 1982; Balasundaram and Sarbhoy, 1988; Harrison and Stewart, 1988; Hussain et al., 1990; Singh et al., 2008).

Application of biological control using antagonistic microorganisms against seed and root rot pathogens proved to be sussccfully and its efficiency in controlling many diseases and improving vegetative growth and yield quality of many crops was recorded (Adams, 1990; Farzana and Ghaffar, 1991; Callan et al., 1997). Coating seeds of many crops with bio control agents such Trichoderma spp., Bacillus subtilis, Psedomonas florocense were the most effective treatments for controlling many seed and soil borne pathogens (Adams, 1990; Abd -Kareem, 2002; Harman et al.,
1989; Lacicowa and Pieta, 1996; Ragab et al., 1999).

However, biological seed treatments may not provide adequate seed protection under all condition as bio-protection may be fail to establish on seed or in the rhizospher at sufficient level for disease control (Baird $e t$ al., 1994;Osburn and Scharoth, 1989;). Bacillus spp. is one of the biological control agents that has shown inhibitory effects against a considerable number of plant pathogens, and the antibiotics that it produces are generally assumed to be responsible for the control activity (Helbig et al., 1998; Krebs et al., 1998). Some authors have suggested that the use of antimicrobially active species and strains of the genus Bacillus, or the use of their metabolites, may be an alternative or supplementary method to chemical plant protection (Berger et al., 1996; Handelsman et al., 1990; Klich et al., 1994; Sharga and Lyon, 1998). Many of these bacilli are generally soil-inhabiting bacteria or exist as epiphytes and endophytes in the spermosphere (Walker et al., 1998) and rhizosphere (Handelsman et al., 1990; Kajimura et al., 1995; McKeen et al., 1986). For this reason, Bacillus species are ideal candidates for use as biocontrol agents in seed treatment programs against soil-borne pathogens (Walker et al., 1998).

B. subtilis, B. amyloliquefaciens, and B. pumilus have a background of being biological control agents against diverse soil pathogens (El-Hassan and Gowen, 2006; Liu et al., 2008; Szczech and Shoda, 2006; Yu et al., 2002;).

The effects of Pseudomonas spp. in plant growth promotion have been observed (Lemanceau, 1992). The beneficial effects of these bacteria have been attributed to their ability to promote plant growth and to protect the plant against pathogenic micro 
organisms. The fluorescent Pseudomonads have been applied successfully to suppress Fusarium wilts of various plant species (Lemanceau and Alabouvette, 1993). Moreover, various secondary metabolites secreted by Pseudomonas spp., including $\mathrm{HCN}$ and siderophores, have been found to be inhibitory against different phytopathogens (Bagnasco et al., 1998; Siddiqui, 2006).

Enhancement of plant-pathogen biological control agents may improve alternative measures instead of chemical measures. For example, several attempts have been made to use the biocontrol approach against severe diseases of crop plants. Several studies have reported the antagonistic effects of Streptomyces spp. on plant pathogens, for example: S. rochei on Phytopthora root rot of pepper (Ezziyyani et al., 2007); S. griseoviridis on Fusarium root rot and wilt of tomato (Minuto et al., 2006); S. platensis on $R$. solani leaf blight/seedling blight of rice (Wan et al., 2008); S. hygroscopicus on Colletotrichum gloeosprioides anthacnose of several crops (Prapagdee et al., 2008).

fluorescent Pseudomonas has been suggested as potential biological control agent due to its ability to colonize rhizosphere and protect plants against a wide range of important agronomic fungal diseases such as black root-rot of tobacco (Voisard et al., 1989), root-rot of pea ( Papavizas and Ayers, 1974), root-rot of wheat (Garagulia ,1974), damping-off of sugar beet (Fenton et al.,1992 ; Shanahan et al., 1992; Kumar et al., 2002) and as the prospects of genetically manipulating the producer organisms to improve the efficacy of these biocontrol agents (Dowling and Gara, 1994).

Several reports have shown the potential of Pseudomonas species as BCAs for controlling plant and fruit diseases (Botelho and Hagler, 2006; Jayaraj et al., 2007; Okubara et al., 2004; Trivedi et al., 2008; Walsh et al., 2001;).

In conclusion, chemical fertilization is a very common method of providing plants with their necessary nutrients because of its rapid effects on plant growth and yield production. However, there are important issues regarding the use of chemical fertilizers, as their improper and excess use can adversely affect the environment. Accordingly, it is important to indicate the contribution of chemical and biological fertilization to the plant growth. PGPR are likely to be of great interest in sustainable crop protection and growth promotion. However, the effective use of these rhizobacteria sometimes fails because PGPR are unable to recolonize the rhizosphere of the inoculated plants. Moreover, the soil persistence of bacteria may be influenced by a number of biotic and abiotic factors. It has also been reported that PGPR isolated from native rhizosphere are more effective in growth enhancement and crop protection than other strains because of better adaptability of bacterial strains.A promising strategy for the replacement and/or supplement of chemicals is the implementation of Biocontrol technology, used individually or as an integrated control component (Akrami et al., 2009).

Application of PGP Bacteria in organic farming can be effectively used to increase the efficiency of fertilizer similar to mineral fertilizer. In view of environmental pollution in the case of excessive use of mineral fertilizers and high production costs of $\mathrm{N}$ and $\mathrm{P}$ fertilizers, bacteria tested in our study may suited alone or in combination to achieve sustainable and ecologically safe agricultural production in the Andaman region. 
Plant pathogens include fungi are the most visible threats to sustainable food production. The decreasing efficacy of the fungicides as well as risks associated with fungicide residues on the leaves and fruit, have highlighted the need for a more effective and safer alternative control measures. In recent years, biological control of plant pathogens has received increasing attention as a promising supplement or alternative to chemical control.

Biological control of plant disease is defined as "The involvement of the use of beneficial microorganisms, such as specialized fungi or yeast or bacteria to attack and control the plant pathogens (i.e., fungi, bacteria, nematodes or weeds) and the diseases they are causing (Cook, 1994 and Fravel, 2005). Biological control is a potent means of reducing the damage caused by plant pathogens (Jeyarajan and Nakkeeran, 2000 and Haggag; Wafaa, 2002). A promising strategy for the replacement and/or supplement of chemicals is the implementation of Biocontrol technology, used individually or as an integrated control component (Akrami et al., 2009).

The appropriate use of fertilization, which is a combination of chemical and biological fertilization, can very much contribute to the enhanced food production in the world, while economically and environmentally recommendable. These strains could be useful in the formulation of new inoculants, improving the cropping systems into which it can be most profitably applied.

\section{References}

Adekunle, A.K., Cardwell, D., and Florini Ikotum, T., 2001. Seed treatment with Trichoderma species for control of damping-off of cowpea caused by Macrophomina phaseolina. Biocontrol Science Technology. 11: 449-457.
Adesemoye, A.O., Obini, $\mathrm{M}$ and Ugoji, E.O., 2008. Comparison of plant growth promotion with Pseudomonas aeruginosa and Bacillus subtilis in three vegetables. Brazilian Journal of Microbiology. 39: 423442.

Afzal and Asghari., 2008. Rhizobium and phosphate solubilizing bacteria improve the yield and phosphorus uptake in wheat. International Journal of Agriculture and Biology. 10: 85-88.

Ahmad, F., Ahmad, I and Khan, M.S., 2005. Indole acetic acid production by the indigenous isolated of Azotobacter and Fluorescent Pseudomonas in the presence and absence of tryptophan. Turkish Journal of Biology. 29: 29-34.

Ahmad, F., Ahmad, I and Khan, M.S., 2008. Screening of free-living rhizospheric bacteria for their multiple plant growth promoting activities. Microbial Research. 163: 173-81.

Alexander, D.B and Zuberer, D.A., 1991. Use of chrome azurol $S$ reagents to evaluate siderophore production by rhizosphere bacteria. Biology and Fertility of Soils. 12: $39-45$.

Amara, M.A.T and Dahdoh, M.S.A., 1997. Effect of inoculation with plant growthpromoting rhizobacteria (PGPR) on yield and uptake of nutrients by wheat grown on sandy soil. Egyptian Journal of Soil Science. 37: 467-484.

Anjum, M.A., Sajjad, M.R., Akhtar, N., Qureshi, M.A., Iqbal, A., Jami, A.R and Hasan, M., 2007. Response of cotton to plant growth promoting rhizobacteria (PGPR) inoculation under different levels of nitrogen. Journal of Agricultural Research. 45: 135-143.

Antoun, H and Kloepper, J.W., 2001. Plant Growth Promoting Rhizobacteria. In: Brenner S, Miller JF (Eds), Encyclopedia of Genetics, Academic Press. 1477-1480.

Arkhipova, T.N., Veselov, S.U., Melantiev, A.I., Marty, N.E.V and Kudoyerova, G.R., 2005. Ability of bacterium Bacillus to produce cytokinins and to influence the growth and endogenous hormone content of lettuce plants. Plant and Soil. 272: 201-209.

Arshad, M and Frankenberger, W.T., 1991. Microbial production of plant hormones. 
Plant and Soil. 133: 1-8.

Arshad, M and Frankenberger, W.T., 1992. Microbial production of plant growth regulators. In: Soil Microbial Ecology. 307347.

Asghar, H.N., Zahir, Z.A., Arshad, M and Khalig, A., 2002. Plant growth regulating substances in the rhizozphere: microbial productionand functions. Advances in Agronomy. 62: 146151.

Asghar, H.N., Zahir, Z.A., Arshad, $\mathrm{M}$ and Khaliq, A., 2002. Releationship between In vitro production of auxins by rhizobacteria and their growth promoting activities in Brassica juncea L. Biology and Fertility of Soils. 35: 231-237.

Ashrafuzzaman, M., Hossen, F.A., Razi-Ismail, M., Hoque, M.A., Zahurul-Islam, M., Shahidullah S.M and Meon S., 2009. Efficiency of plant growth-promoting rhizobacteria for the enhancement of rice growth. Africal Journal of Biotechnology. 8:1247-1252.

Baird, R.E., Nankam, C., Moghaddam, P.F and Pataky, J.K., 1994. Evaluation of seed treatments on shunken 2 sweet corn. Plant Disease.78: 817-821.

Bakker, A.W and Schippers, B., 1987. Microbial cyanide production in the Rhizosphere in relation to potato yield reduction and Pseudomonas spp. mediated plant growth stimulation. Soil Biology and Biochemistry. 19: 451-457.

Balasundaran, V and Sarbhoy, A., 1988. Inhibition of plant pathogenic fungi by Rhizobium japonicum. Indian Phytopathology. 41: 128-130.

Barzanti, R, Ozino F., Bazzicalupo, M., Gabbrielli, R., Galardi, F and Gonnelli, C., 2007. Isolation and characterization of endophytic bacteria from the nickel hyperaccumulator plant Alyssum bertolonii. Microbial Ecology. 53: 306-316.

Bell, D., K. Wells, H and Markham, C.R., 1982. In vitro antagonism of Trichoderma species against six fungal plant pathogens. Phytopathology. 72: 379-382.

Benizri, E., Courtade, A., Picard, C and Guckert, A., 1998. Role of maize root exudates in the production of auxins by Pseudomonas fluorescens M.3.1. Soil Biology and Biochemistry. 30:1481-1484.

Bent, E., Breuil, C., Enebak, S and Chanway, C.P., 2002. Surface colonization of lodgepole pine (Pinus contorta var. latifolia roots by Pseudomonas fluorescens and Paenibacillus polymyxa under genotobiotic conditions. Plant and Soil. 241: 187-196.

Berg, G., Frankowski, J., Krechel, A., Lottmann, J., Ribbeck, K., Roder, A and Wolf, A., 2003. Plant associated bacteria diversity antagonistic interactions and biotechnological applications. Research Advance in Microbiology. 3: 23-33.

Berg, G., Roskot, N., Steidle, A., Eberl, L., Zock A and Samalla, K., 2002. Plant-Dependent Genotypic and Phenotypic Diversity of Antagonistic Rhizobacteria Isolated from different Verticillium Host Plants. Applied and Environmental Microbiology. 68: 3328-3338.

Berger, F., Li, H., White, D., Frazer, R and Leifert, C., 1996. Effect of pathogen inoculum, antagonist density, and plant species on biological control of Phytophtora and Pythium damping-off by Bacillus subtilis Cot1 in high-humidity fogging glasshouses. Phytopathology. 86: 428-433.

Bin, L., Smith, D.L and Ping-Qui F., 2000. Application and mechanism of silicate bacteria in agriculture and industry. Guizhou Science. 18: 43-53.

Biswas, J.C., Ladha, J.K and Dazzo, F.B., 2000. Rhizobial inoculation influences seedling vigor and yield of rice. Agronomy Journal. 92: 880-886.

Bloemberg, G.V and Lugtenberg, B.J.J., 2001. Molecular basis of plant growth promotion and biocontrol by rhizobacteria. Current Opinion in Biotechnology. 4: 343-350.

Boddey, R.M and Dobereiner, J., 1995. Nitrogen fixation associated with grasses and cereals: recent progress and perspectives for the future. Fertilizer research. 42: 241-250.

Botelho, G.R and Hagler, L.C.M., 2006. Fluorescent Pseudomonads associated with the rhizosphere of crops - An overview. Brazilian Journal of Microbiology. 37: 401416.

Bottini, R and Luna, V., 1993. Bud dormancy in deciduous fruit trees. Current Topics in Plant Physiology. 1:147-159 
Boyer, G.L., Kane, S.A., Alexander, J.A and Aronson, D.B., 1999. Siderophore formation in iron-limited cultures of Frankia sp. strain 52065 and Frankia sp. strain CeSI5. Canadian Journal of Botany. 77: 1316-1320

Burd, G.I., Dixon, D.G and Glick, B.R., 2000. Plant growth-promoting bacteria that decrease heavy metal toxicity in plants. Canadian Journal of Microbiology.46: 23745.

Burr, T.J and Caesar, A., 1984. Beneficial plant bacteria. Critical Reviews in Plant Sciences. 2:1-20.

Buysens, S., Heungens, K., Poppe, J and Hofte, M., 1996. Involvement of pyochelin and pyoverdin in suppression of Pythiuminduced damping-off of tomato by Pseudomonas aeruginosa7NSK2. Applied Environmental Microbiology. 62: 865-871.

Cakmakci, R., 2005a. Bitki gelifliminde fosfat cozucu bakterilerin onemi. Selcuk Univ. Ziraat Fakultesi Dergisi. 35: 93-108.

Cakmakci, R., 2005b. Bitki geliflimini teflvik eden rizobakterilerin tarımda kullanımı. Ataturk Univ. Ziraat Fakultesi Dergisi. 36: 97-107.

Cakmakci, R., Donmez, F., Aydın, A and Sahin, F., 2006. Growth promotion of plants by plant growth-promoting rhizobacteria under greenhouse and two different field soil conditions. Soil Biology and Biochemistry. 38:1482-148.

Cakmakci, R., Kantar, F., and Algur, O.F., 1999. Sugar beet and barley yields in relation to Bacillus polymyxa and Bacillus megaterium var. phosphaticum inoculation. Journal of Plant Nutrition and Soil Science. 162: 437442.

Cakmakcy, R., Erat, M., Erdoan, U.G and Donmez, M.F., 2007. The influence of PGPR on growth parameters, antioxidant and pentose phosphate oxidative cycle enzymes in wheat and spinach plants. Journal of Plant Nutrition and Soil Science. 170: 288-295.

Callan, N.W., Mathre, D.E., Miller, I.B and Vavrina, C.S., 1997. Biological seed treatments, factors affecting their efficacy. Horticultural Science. 32: 197-183.
Carrillo-Castaneda, G., Juarez Munos, J., PeraltaVidea, J.R., Gomez, K., Tiemannb, K.J., Duarte-Gardea, $\mathrm{M}$ and Gardea-Torresdey, J.H., 2002. Alfalfa growth promotion by bacteria grown under iron limiting conditions. Advances in Environmental Research. 6: 391399.

Castric, P., 1994. Influence of oxygen on the Pseudomonas aeruginosa hydrogen cyanide synthase. Current Microbiology. 29:19-21.

Castric, P.A., 1975. Hydrogen cyanide, a secondary metabolite of Pseudomonas aeruginosa. Canadian Journal Microbiology. 21: 613-618.

Cattelan, A.J., Hartel, P.G and Fuhrmann, J.J., 1999. Screening for Plant GrowthPromoting Rhizobacteria to Promote Early Soybean Growth. Soil Science Society of America Journal. 63: 1670-1680.

Chakraborty, U., Chakraborty, B and Basnet, M., 2006. Plant growth promotion and induction of resistance in Camellia sinensis by Bacillus megaterium. Journal of Basic Microbiology. 46: 186-195.

Chandrasekharam, D., Santo, A.P., Capaccioni, B., Vaselli, O., Alam, M.A., Manetti, P and Tassi, F., 2009. Volcanological and petrological evolution of Barren Island (Andaman Sea, Indian Ocean). Journal of Asian Earth Science. 35: 469-487.

Chanway, C.P., 1998. Bacterial endophytes: ecological and practical implications. Sydowia 50:149-170.

Charan, A.R., Reddy, V.P., Reddy, P.N and Reddy, S.S., 2011. Assessment of genetic diversity in Pseudomonas fluorescens using PCR-based methods. Bioremediation, Biodiversity and Bioavailability. 5, 10-16.

Chen, C., Bauske, E.M., Musson, G., RodriguezKabana, R and Kloepper, J.W., 1994. Biological control of Fusarium on cotton by use of endophytic bacteria. Biological Control. 5: 83-91.

Chen, W and Kuo, T., 1993. A simple and rapid method for preparation of bacterial genomic DNA. Nucleic Acid Res. 21(8): 2260-2262.

Chen, Y.P., Rekha, P.D., Arun, A.B., Shen, F.T., Lai, W.A and Young, C.C., 2006. Phosphate solubilizing bacteria from subtropical soil and their tricalcium phosphate solubilizing abilities. Applied 
Soil Ecology. 34: 33-41.

Chernin, L., Ismailov, Z., Haran, S and Chet, I., 1995. Chitinolytic Enterobacter agglomerans antagonistic to fungal plant pathogens. Applied Environental Microbiology. 61:17201726.

Cook, R.J., and Baker, K.F., 1983. The Nature and Practice of Biological Control of Plant Pathogens. APS Press, St. Paul

Cordovilla, M.P., Ocana, A., Ligero, F and Lluch, C., 1995. Salinity effects on growth analysis and nutrientcomposition in four grain legumes-Rhizobium symbiosis. Journal of Plant Nutrition. 18: 1595 -1609.

Cutler, H.G and Hill, R.A., 1994. Natural fungicides and their delivery systems as alternate to synthetics. In: Biological Control of Postharvest Diseases. 135-142.

Dastager, S.G., Deepa, C.K and Pandey, A., 2010. Potential plant growth promoting activity of Serratia nematophila NII- 0.928 on black papper (Piper nigrum L). World Journal of. Microbiology and Biotechnology. 27: 259-265.

Davies, P.J., 1995. Plant hormones physiology, biochemistry and molecular biology, 2nd edn. Dordrecht: Kluwer Academic Publishers. 112.

De Freitas, J.R., 2000. Yield and $\mathrm{N}$ assimilation of winter wheat (Triticum aestivum L) inoculated with rhizobacteria. Pedobiologia. 44: 97-104.

De Freitas, J.R., Banerjee, M.R and Germida, J.J., $\quad 1997 . \quad$ Phosphatesolubilizing rhizobacteria enhance the growth and yield but not phosphorus uptake of canola (Brassica napus L.). Biology and Fertility of Soils. 24: 358-364.

Dey, R., Pal, K.K., Bhatt, D.M and Chauhan, S.M., 2004. Growth promotion and yield enhancement of peanut (Arachis hypogaea L.) by application of plant growthpromoting rhizobacteria. Microbiological Research. 159: 371-394.

Diarra, M.S., Mckee, J.A., Dolence, E.K., Darwish, I., Miller, M.J., Malouin, F and Jacques, M., 1996. Growth of Actinobacillus pleuropneumoniae is promoted by exogenous hydroxamate and catechol siderophores. Applied and Environmental Microbiology. 62: 853-859.
Diaz, M.E., Villa, P and Frias, A., 2002. Evaluation of the siderophores production by Pseudomonas aeruginosa PSS. Revista Latinoamericana de Microbioloogia. 44: 112-117.

Dimkpa, C.O., Svatos, A., Dabrowska, P., Schmidt, A., Boland, W and Kothe, E., 2008. Involvement of siderophores in the reduction of metal-induced inhibition of auxin synthesis in Streptomyces spp. Chemosphere .74:19-25.

Dobbelaere, S., Vanderleyden, J and Okon Y., 2003 Plant growthpromoting effects of diazotrophs in the rhizosphere. Critical Reviews in Plant Sciences. 22: 107-149.

Dodman, R.L and Flentije, N.T., 1985. The mechanism and physiology of plant penetration by Rhizoctonia solani. In: J.R Parameter Jr. (Eds), Rhizoctonia solani. Biology and Pathology. 147-160.

Doman, R.L., Baker, K.R and Walker, J.C., 1968. A detailed study of the different mode of penetration by Rhizoctonia solani. Phytopathology. 58: 1271-1276.

Domsch, K.H., Gams, W and Anderson, T.H., 1980. Compendium of Soil Fungi. Academic Press, London, NewYork.

Dong-Woo, L., You-Seok, K., Ki Jun, K., Byung-Chan, K., Hak- Jong, C., Doo-sik, K., Maggy, T and Yu-ryang, P., 1999. Isolation and characterisation of thermophilic lipase from Bacillus the rmoleovorans ID-1. FEMS Microbiology Letters. 179: 393-400.

Dowling, D.N and O'Gara, F., 1994. Metabolites of Pseudomonas involved in the biocontrol of plant disease. Trends in Biotechnology.12: 133-141.

Dunn, C., Crowley, J.J., Moenne-Loccoz, Y., Dowling, D.N., De Bruijn, F.J and O'Gara, F., 1997. Biological control of Pythium ultinum by Stenotrophomonas maltophilia W18 is mediated by an extracellular proteolytic activity. Microbiology. 143: 3921-3931.

Dunne, C., Moenne-Loccoz, Y., De Bruijn, F.J and O'Gara, F., 2000. Overproduction of an inducible extracellular serine protease improves biological control of Pythium ultimum

Stenotrophomonas maltophilia strain 
W81. Microbiology. 146: 2069-2078.

Dvornikova, T.P., Skryabin, G.K and Suvorov, N.N., 1970. Enzymatic transformation of tryptamine by fungi. Microbiology. 39: 3235.

Elad, Y and Shtienberg, D., 1996. Trichoderma harzianum T39 (Trichodex) integrated with fungicides for the control of grey mould of strawberry, vegetable, greenhouse crops and grapes. In: Advances in Biological Control of Plant Diseases.

El-Hassan, S.A and Gowen, S.R., 2006. Formulation and delivery of the bacterial antagonist Bacillus subtilis for management of lentil vascular wilt caused by Fusarium oxysporum f. sp. lentis. Journal of Phytopathology. 154: 148-155.

Esitken, A., Karlidag H., Ercisli S., Turan, M and Sahin, F., 2003.The effects ofspraying a growth promoting bacteriumon the yield, growth and nutrientelement composition of leaves of apricot (Prunus armeniaca L.). Australian Journal of Agricultural Research. 54: 377-380.

Ezziyyani, M., Requena, M.E., Egea-Gilabert, C and Candela, M.E., 2007. Biological control of phytophthora root rots of pepper using Trichoderma harzianum and Streptomyces rochei in combination. Phytopathology. 155: 342-349.

Fenton, A.M., Stephens, P.M., Crowley, J., O'Callaghan, $\mathrm{M}$ and O'Gara, F., 1992. Exploitation of gene(s) involved in 2, 4diacetylphloroglucinol biosynthesis to confer a new biocontrol capability to a Pseudomonas strain. Applied and Environmental Microbiology. 58: 3873-3878.

Finnie, J.F and Van Staden, J., 1985. Effect of seed weed concentrate and applied hormones on in vitro cultured tomato roots. Journal of Plant Physiology. 120: 215-222.

Flaishman, M.A., Eyal, Z.A., Zilberstein, A., Voisard, C and Hass, D., 1996. Suppression of Septoria tritciblotch and leaf rust of wheat by recombinant cyanide producing strains of Pseudomonas putida. Molecular Plant Microbe Interaction. 9: 642-645.

Frankenberger, W.T and Brunner, W., 1983. Methods of detection of auxinindole acetic acid in soil by high performance liquid chromatography. Soil Society Amarican Journal. 47: 237-241.
Fravel, D.R., 2005. Commercialization and implementation of biocontrol. Annual Review of Phytopathology. 43: 337-359.

Gangwar, M and Kaur, G., 2009. Isolation and characterization of endophytic bacteria from endorhizosphere of sugarcane and ryegrass. The International Journal of Microbiology. $7: 1$.

Gaur, A.C., 1990. Physiological functions of phosphate solubilizing micro-organisms, Phosphate Solubilizing Micro-organisms as Biofertilizers. Omega Scientific Publishers, New Delhi. 16-72.

Glick, B.R and Bashan, Y., 1997. Genetic manipulation of plant growth-promoting bacteria to enhance biocontrol of phytopathogens. Biotechnology Advances. 15:353-378.

Glick, B.R and Pasternak, J.J., 2003. Plant growth promoting bacteria. In: Glick B.R, Pasternak J.J (Eds) Molecular biotechnology principles and applications of recombinant DNA, 3rd edn. ASM Press, Washington. 436-454.

Glick, B.R., 1995. The enhancement of plant growth by free living bacteria. Canadain Journal of Microbiology. 41: 109-114.

Glick, B.R., 1995. The enhancement of plant growth by free-living bacteria. Canadian Journal of Microbiology. 41: 109-117.

Glick, BR., 2001. Phytoremediation: synergistic use of plants and bacteria to cleanup the environment. Biotechnology Advance. 21: 83-393.

Goldstein, A.H., 1986. Bacterial solubilization of microbial phosphates: a historical perspective and future prospects. American Journal of Alternative Agriculture. 1: 51-57.

Goldstein, A.H., 1995. Recent progress in understanding the molecular genetics and biochemistry of calcium phosphate solubilization by Gram negative bacteria. Biological Agriculture and Horticulture. 12: 185-193.

Goldstein, A.H., Braverman, K and Osorio, N., 1999. Evidence for mutualism between a plant growing in a phosphate-limited desert environment and a mineral phosphate solubilizing (MPS) bacterium. FEMS Microbiology Ecology. 3: 295-300.

Goto, M., 1990. Fundamentals of Bacterial Plant 
Pathology. Academic Press, San Diego.

Gull, F.Y., Hafeez, I., Saleem, M and Malik, K.A., 2004. Phosphorus uptake and growth promotion of chickpea by co-inoculation of mineral phosphate solubilizing bacteria and a mixed rhizobial culture. Australian Journal of Experimental Agriculture .44: 623-628.

Guo, J.H., Qi, H.Y., Guo, Y.H., Ge, H.L., Gong, L.Y and Zhang, L.X., 2004. Biocontrol of tomato wilt by plant growth promoting rhizobacteria. Biological Control. 29: 6672.

Gutierrez-Manero, F.J., Ramos-Solano, B., Probanza, A., Mehouachi, J., Tadeo, F.R and Talon, M., 2001. The plant growthpromoting rhizobacteria Bacillus licheniformis produce high amounts of physiologically active gibberillins. Physiologia Plantarum. 111: 206-211.

Gyaneshwar, P., Kumar, G.N., Parekh, L.J and Poole, P.S., 2002. Role of soil microorganisms in improving $\mathrm{P}$ nutrition of plants. Plant and Soil. 245: 83-93.

Haas, D and Defago, G., 2005. Biological control of soil-borne pathogens by fluorescent pseudomonads. Nature Reviews Microbiology. 3: 307.

Handelsman, J., Raffel S., Mester, E.H., Wunderlich, L and Grau, CR., 1990. Biological control of damping-off of alfalfa seedlings with Bacillus cereus UW85. Applied Environmental Microbiology. 56: 713-718.

Harman, G.E., Hayes, C.K., Lorito, M., Broadway, R.M., Di Pietro, A., Peterbaues, C and Tronsmo, A., 1993. Chitinolytic enzymes of Trichoderma harzianum: purification of chitobiosidase and endochitinase. Phytopathology. 83: 313318.

Harman, G.F., Taylor, A.G and Stasz, T.E., 1989. Combining effective strains of Trichoderma horzianum and solid matrix priming to improve biological control seed treatment. Phytopathology.73: 631-637.

Helbig, J., Trierweiler, B., Schulz, FA and Tauscher, B., 1998. Inhibition of Botrytis cinerea and Penicillium digitatum Sacc by Bacillus spp. (Isolate 17141) In vitro. Journal of Plant Disease Protection. 105: 8-
16.

Hilda, R and Fraga, R., 1999. Phosphate solubilizing bacteria and their role in plant growth promotion. Biotechnology Advance. 17: 319-359.

Hobday, J. R and Mallet, F. R., 1885. The Volcanoes of Barren and Narcondam Islands in the Bay of Bengal. Geological Survey of India. 21: 251-286.

Husen, E., 2003. Screening of soil bacteria for plant growth promotion activities in vitro. Indonesian Journal of Agricultural Sciences. 4: 27-31.

Idris, S.E., Iglesias, D.J, Talon, $\mathrm{M}$ and Borriss, R., 2007. Tryptophan-dependent production of Indole-3-Acetic Acid (IAA) affects level of plant growth promotion by Bacillus amyloliquefaciens FZB42. Molecular PlantMicrobe Interactions. 20 : 619-626.

Imbert, M., Bechet, M and Blondeau, R., 1995. Comparison of the main siderophore produced by some species of Streptomyces. Current Microbiology. 31: 129-133.

Jayaraj, J., Parthasarathi, T and Radhakrishnan, N.V., 2007. Characterization of a Pseudomonas fluorescens isolate from tomato rhizosphere and its use for integrated management of tomato damping-off. Biocontrol. 52: 683-702.

Jetiyanon, K and Kloepper, J.W., 2002. Mixtures of plant growth promoting rhizobacteria for induction of systemic resistance against multiple plant diseases. Biological Control .24:285-291.

Jeyarajan, R and Nakkeeran, S., 2000. Exploitation of microorganisms and viruses as biocontrol agents for crop disease mangement. In : Biocontrol Potential and their Exploitation in Sustainable agriculture, (Ed. Upadhyay et al.,) Kluwer Academic/ Plenum Publishers, USA. 95-116.

Jijakli, H.M and Lepoivre, P., 1998. Characterization of an exo- $\beta-1,3$ glucanase produced by Pichia anomala strain K, antagonist of Botrytis cinerea on apples. Phytopathology. 88: 335-343.

Joo, G.J., Kim, Y.M., Lee, K.I.J., Song, S and Rhee, I.K., 2004. Growth promotion of red pepper seedlings and the production of gibberellins by Bacillus cereus, Bacillus macroides, Bacillus pumilus. Biotechnology 
Letters. 26: 487-491

Kajimura, Y., Sugiyama, M and Kaneda, M., 1995. Bacillopeptins, new cyclic lipopeptide antibiotics from Bacillus subtilis FR-2. Journal of Antibiotics. 48: 1095-1103.

Kampert, M, Strzelczyk, E and Pokojska, A., 1975. Production of auxins by bacteria isolated from pine roots (Pinus syivestris L.) Acta Microbiology. 7: 135-143.

Karnwal, A., 2009. Production of indol acetic acid by Fluorescent Pseudomonas in the prescence of L-Tryptophan and Rice root exudates. Journal of Plant Pathology. 91: 61-63.

Khalid, A, Arshad, M and Zahir, Z.A., 2004. Screening plant growth promoting rhizobacteria for improving growth and yield of wheat. Journal of Applied Microbiology. 96: 473-480.

Kim, K.Y., Jordan, D and McDonald, G.A., 1998. Enterobacter agglomerans, Phosphate Solubilizing Bacteria and Microbial Activity in Soil: Effect of Carbon Source. Soil Science Society of America. 30: 995-1003.

Klich, M.A., Arthur, K.S., Lax, A.R and Bland, J.M., 1994. Iturin A: a potential new fungicide for stored grains. Mycopathologia. 127:123-127.

Kloepper, J.W., 1992. Plant growth-promoting rhizobacteria as biological control agents. In: Soil Microbial Ecology: Applications in Agricultural and Environmental Management. 255-274.

Kloepper, J.W., Leong J., Teintze, $\mathrm{M}$ and Schroth, M.N., 1980. Enhanced plant growth by siderophores produced by plant growth promoting rhizobacteria. Nature. 286: 885- 886.

Knowles, C.J and Bunch, A.W., 1986. Microbial cyanide metabolism. Advances in Microbial Physiology. 27: 73-111.

Kraemer, Stephan M., Crowley, David Kretzschmar and Ruben., 2006. Siderophores in Plant Iron Acquisition: Geochemical Aspects. Advances in Agronomy. 91: 1-46.

Krebs, B., Hoding, B., Kubart, S., Alemakehau, W., Junge, H., Chmideknecht, G.S., Grosch, $\mathrm{R}$ and Bochow, H., 1998. Use of Bacillus subtilis as Biocontrol agent. Activities and charecteriztion of Bacillus subtilis strains-Z. Pflkrankh Pflschutz.105:187-197.

Kumar, N.R, Arasu, V.T and Gunasekaran, P., 2002. Genotyping of antifungal compounds producing plant growth-promoting rhizobacteria, Pseudomonas fluorescens. Current Science. 82: 1465-1466.

Lacicowa, B and Pieta, D., 1996. The efficiency of microbiological dressing of pea seeds (Pisum sativium) against pathogenic soil borne fungi. Rocznik nauk Rolniczych Seria, E. Ochrona. Roslin. 25: 15-21.

Laville, J., Blumer, C., Von Schroetter, C., Gaia, V., De! fago, G., Keel, $\mathrm{C}$ and Haas, D.,1998. Characterization of the henABC gene cluster encoding hydrogen cyanide synthase and anaerobic regulation by ANR in the strictly aerobic biocontrol agent Pseudomonas fuorescens CHA0. Journal of Bacteriology. 180: 3187-3196.

Lemanceau, P and Alabouvette, C., 1993. Suppression of Fusarium wilts by fluorescent pseudomonas: mechanisms and applications. Biocontrol Science and Technology. 3: 219234.

Lemanceau, P., 1992. Effects benefical de rhizobacteries surles plantes example des pseudomonas spp. Agronomine.12:413-437

Liu, T, Wang, L, Duan, Y.X and Wang, X., 2008. Nematicidal activity of culture filtrate of Beauveria bassiana against Meloidogyne hapla. World Journal of Microbial Biotecnology. 24:113-118.

Liu, W.T., Marsh, T.L., Cheng, $\mathrm{H}$ and Forney, L.J., 1997. Characterization of microbial diversity by determining terminal restriction fragment length polymorphisms of genes encoding 16S rRNA. Applied Environmental Microbiology. 63: 45164522.

Loper, J.E and Buyer, J.S., 1997. Siderophores in microbial interactions on plant surfaces. Molecular Plant Microbe Interaction. 4: 513.

Loper, J.E and Henkels, M.D., 1999. Utilization of heterologous siderophores enhances levels of iron available to Pseudomonas putida in the rhizosphere. Applied. Environmental Microbiology. 65: 53575363.

Loper, J.E., 1988. Role of fluorescent 
siderophore production in biological control of Pythium ultirnum by a Pseudomonas fluorescens strain. Phytopathology.78 : 166172.

Lucas, G.J.A., Probanza, A., Ramos, B., Colon Flores, J.J and Gutierrez Manero, F.J., 2004. Effect of plant growth promoting rhizobacteria (PGPRs) on biological nitrogen fixation, nodulation and growth of Lupinus albus I. cv. Multolupa. Engineering in Life Science 7:1-77.

Luthen, H., Claussen, M and Bottger, M., 1999. Growth: progress in auxin research. Cell Biololgy Physiology.Progress in Botany. 60: 315-340.

Lynch, J.M., 1985. Origin, nature and biological activity of aliphatic substances and growth hormones found in soil. In: Soil Organic Matter and Biology.151-174.

Maa, Y., Prasadb, M.N.V., Rajkumarc, M and Freitasa, H., 2011. Plant growth promoting rhizobacteria and endophytes accelerate phytoremediation of metalliferous soils. Biotechnology Advances. 29: 248-258.

Maleki, M., Mostafee, S., Mokhaternejad, L and Farzaneh, M., 2010. Characterization of Pseudomonas fluorescens strain CV6 isolated from cucumber rhizosphere in Varamin as a potential biococntrol agent. Australian Journal of Crop Science. 4: 676683.

Martinez, J.L., Delgado-Iribarren, $A$ and Baquero, F., 1990. Mechanisms of iron acquisition and bacterial virulence. FEMS Microbiology Review. 75: 45-56.

Martinez, J.L., Delgado-Iribarren, $A$ and Baquero, F., 1990. Mechanisms of iron acquisition and bacterial virulence. FEMS Microbiology Review. 75: 45-56.

Mass, J.L and and Galletta, G.J., 1997. Recent progress in strawberry disease research. Acta Horticulturae. 439: 769-780.

McKeen, C.D, Reilly, C.C and Pusey, P., 1986. Production and partial characterization of antifungal substances antagonistic to Monilinia fructicola from Bacillus subtilis. Phytopathology.76: 136-139.

Meziane, H., Van Der Sluis, I., Van Loon, L.C., Hofte, $\mathrm{M}$ and Bakker, P.A.H.M., 2005. Determinants of Pseudomonas putida WCS358 involved in inducing systemic resistance in plants. Molecular Plant Pathology. 6: 177-185.

Mia, M.A.B., Shamsuddin, Z.H., Wahab, Z and Marziah, M., 2010. Effect of plant growth promoting rhizobacterial (PGPR) inoculation on growth and nitrogen incorporation of tissue cultured Musa plantlets under nitrogen-free hydroponics condition. Australin Journal of Crop Science. 4 :85-90.

Minuto, A., Spadaro D., Garibaldi, A and Gullino, M.L., 2006. Control of soilborne pathogens of tomato using a commercial formulation of Streptomy cesgriseoviridis and solarization. Crop Protection. 25: 468475.

Moore., 1989. Biochemistry and physiology of plant 2nd edn. New York: Springer-Verlag Inc. 285.

Mullen, M.D., 1998. Transformations of other elements. In Sylvia, D.M.; J.J. Fuhrmann; P.G. Hartel and D.A. Zuberer (Eds.). Principles and Applications of Soil Microbiology.. 369- 386.

Muller, M., Deigele, C and Ziegler, H., 1989. Hormonal interactions in the rhizospheres of maize (Zea mays L.) and their effect on plant development. Z Pflanzenernahar. Bodenkd. 152: $247-254$

Neilands, J.B., 1989. Siderophore systems of bacteria and fungi. In: Doyle, R.J. (Eds), Metal Ions and Bacteria. John Wiley and Sons, New York. 141-163.

Neilands, J.B., 1993. Siderophores. Archives of Biochemistry and Biophysics. 302: 1-3.

Neilands, J.B., 1995. Siderophores: Structure and function of microbial iron transport compounds.The Journal of Biological Chemistry. 45: 26723-26726

Nielson, M.N and Sorensen, J., 1999. Chitinolytic activity of Pseudomonas fluorescens isolates from barley and sugar beet rhizosphere. FEMS Microbiology Ecology. 30: 217-22.

Normanly, J., 1997. Auxin metabolism. Physiology. Plantarum.100: 431-442.

O’Sullivan, D.J and O'Gara, F., 1992. Traits of fluorescent Pseudomonas spp. involved in suppression of plant root pathogens. Microbiology Review. 56: 662-676

Okubara, P.A., Kornoely, J.P and Landa, B.B., 
2004. Rhizosphere colonization of hexaploid wheat by Pseudomonas fluorescens strains Q8r1-96 and Q2-87 is cultivar-variable and associated with changes in gross root morphology. Biological Control 30: 392-403.

Ordentlich, A., Elad, Y and Chet, I., 1988. The role of chitinase of Serratia marcescens in biocontrol of Sclerotium rolfsii. Phytopathology. 78: 48-88.

Osburn, R.M and Scharoth, M.N., 1989. Effect of osmopriming beet seed on germination rate and incidence of Pythium ultimum damping-off. Plant Disease. 73: 21-24.

Owen, A and Zlor, R., 2001. Effect of cyanogenic rhizobacteria on the growth of velvetleaf (Abutilon theophrasti) and Corn (Zea mays) in autoclaved soil and the influence of supplemented glycine. Soil Biochemistry. 33: 801-809.

Pan, B., Bai Y.M., Leibovitch, S and Smith, D.L., 1999. Plant growth promoting rhizobacteria and kinetin as ways to promote corn growth and yield in short season areas. European Jouranl of Agronomy. 11:179-186.

Papavizas, G.C and Ayers, W.A., 1974. Aphanomyces species and their root diseases in pea and sugarbeet. A Review, US Department of Agriculture, Washington DC.

Patten, C.L and Glick, B.R., 1996. Bacterial biosynthesis of Indole-3-acetic acid. Canadian Journal of Microbiology. 42: 207220.

Perkins, J.H and Patterson, B.R., 1997. Pests, pesticides and the environment: a historical perspective on the prospects for pesticide reduction. In: Techniques for Reducing Pesticide Use (Eds): D. Pimental. John Wiley and Sons, Chichester. 13-33.

Perrott, K.W., Sarathchandra, S.U and Dow, B.W., 1992. Seasonal and fertilizer effects on the organic cycle and microbial biomass in a hill country soil under pasture. Australian Journal of Soil Research. 30: 383-394.

Persello-Cartieaux, F., Nussaume, L and Robaglia, C., 2003. Tales from the underground: molecular plant-rhizobacteria interactions. Plant Cell and Environmental.
26: 189-199.

Prapagdee, B., Kuekulvong, C and Mongkolsuk, S., 2008. Antifungal potential of extracellular metabolites produced by Streptomyces hygroscopicus against phytopathogenic fungi. Journal of Biological Science. 4: 330-337.

Ragab, M.M., Aly Mona, M.D.H., Ragab, M.M., and Nehals Mougy, E.L., 1999. Effect of Fungi cides, Biocides and Bioagents on controlling pea root rot diseases. Egypt Journal of Phytopathology. 27: 65-81.

Raj, S.N., Deepak, S.A, Basavaraju, P., Shetty, H.S., Redd.y, M.S and Kloepper, J.W., 2003. Comparative performance of formulations of plant growth promoting rhizobacteria in growth promotion and suppression of downy mildew in pearl millet. Crop Protection. 22: 579-588.

Rajkumar, M., Prasad, M.N.V and Freitas, H., 2010. Potential of siderophore-producing bacteria for improving heavy metal phytoextraction. Trends in Biotechnology.28:142-9.

Rodriguez, H and Fraga, R., 1999. Phosphate solubilizing bacteria and their role in plant growth promotion. Biotechnology Advance. 17: 319-339.

Sandhya, V., Ali, S.K.Z., Grover, M., Reddy, G and Venkatswarlu, B., 2010. Effect of plant growth promoting Pseudomonas spp on compatible solutes, antioxidant status and plant growth of maize under drought stress. Plant Growth Regulation. 62: 21- 30.

Sandoval, V.E., Terzolo, H.R and Blackall, P.J., 1994. Complicated infectious coryza outbreaks in Argentina. Avian Diseases. 38:672-678.

Saravanakumar, D., Lavanya, N., Muthumeena, B., Raguchander, T., Suresh, $\mathrm{S}$ and Samiyappan, R., 2008. Pseudomonas fluorescens enhances resistance and natural enemy population in rice plant.

Scher, F.M and Baker, R., 1982. Effect of Pseudomonas putida and a synthetic iron chelator on induction of soil suppressiveness to Fusarium wilt pathogens. Phytopathology. 72: 1567-1573.

Schippers, B, Bakker, A.W and Baker, P.A.H.M., 1987. Interactions of deleterious and beneficial rhizosphere microorganisms 
and the effect of cropping practices. Annual Review of Phytopathology. 25: 339-358.

Schnider, U., Keel, C., Blumer, C., Troxler, J., De! fago, G and Haas, D., 1995. Amplification of the housekeeping sigma factor in Pseudomonas fuorescens CHA0 enhances antibiotic production and improves biocontrol abilities. Journal of Bacteriology. 177: 5387-5392.

Schwyn, B and Neilands, J.B., 1987. Universal Chemical Assay for the Detection and Determination of Siderophores. Analytical Biochemistry. 160: 47-56.

Shahab, S and Ahmed, N., 2008. Effect of various parameters on the efficiency of zinc phosphate solubilization by indigenous bacterial isolates. African Journal of Biotechnology.

7 :1543-1549.

Shanahan, P., O'Sullvan, D.J., Simpson, P., Glennon, J.D and O'Gara, F., 1992. Isolation and characterization of an antibiotic-like compound from a fluorescent Pseudomonas and investigation of physiological parameters influencing its production. Applied and Environmental Microbiology. 58: 353-358.

Sharga, B.M and Lyon, G.D., 1998. Bacillus subtilis BS 107 as an antagonist of potato blackleg and soft rot bacteria. Canadian Journal of Microbiology. 44: 777- 783.

Silva, V.N., Silva, L.E.S.F and Figueiredo, M.V.B., 2006. Atuacao de rizobios com rizobacte rias promotora de crescimento em plantas na cultura do caupi (Vigna $\begin{array}{lll}\text { unguiculata } & \text { L.). Acta Scientiarum }\end{array}$ Agronomy.28: 407-412

Steinshamn, H, Thuen, E, Bleken, M.A, Brenoe, U.T., Ekerholt, G and Yri, C., 2004. Utilization of nitrogen $(\mathrm{N})$ and phosphorus $(\mathrm{P})$ in an organic dairy farming system in Norway. Agriculture Ecosystems and Environmental. 104: 509-522.

Strzelczyk, E and Pokojska-Burdziej, A., 1984. Production of auxins and gibberellin like substances by mycorrhizal fungi, bacteria and actinomycetes isolated from soil and mycorhizosphere of pine (Pinus silvestris L.). Plant and Soil. 81: 185-194.

Sundara, B., Natarajan, V and Hari, K., 2002. Influence of phosphorus solubilizing bacteria on the changes in soil available phosphorus and sugarcane and sugar yield. Field Crop Research. 77: 43-49.

Szczech, M and M. Shoda., 2006. The effect of mode of application of Bacillus subtilis RB14-C on its efficacy as a biocontrol agent against Rhizoctonia solani. Journal of. Phytopathology. 154: 370-377.

Tilman, D., 1998. The greening of the green revolution. Nature. 396: 211-212.

Trivedi P., Pandey, A and Palni, L.M.S., 2008. In vitro evaluation of antagonistic properties of Pseudomonas corrugata. Microbiological Research. 163: 329-336.

Van Loon, L. C., Rep, $\mathrm{M}$ and Pieterse, C.M.J., 2006. Significance of inducible defenserelated proteins in infected plants. Annual Review of Phytopathology. 44: 135-162.

Van Loon, L.C., Bakker, P.A.H.M and Pieterse, C.M.J., 1998. Systemic resistance induced by rhizosphere bacteria. Annual Review of Phytopathology. 36: 453-483.

Vaneechoutte, M., Dijkshoom, L., Tjenberg, I., Elaichouni, A., Vos de, P., Claeys, G and Verschragen., 1995. Identification of Acinetobacter genomic species by amplified ribosomal DNA restriction analysis. Journal of Clinical Microbiology. 33:11-15.

Venis, M.A and Napier, R.M., 1991. Auxin receptors: recent developments. Plant Growth Regulation. 10: 329-340

Ventosa, A., Garcia, M.T., Kamekura, M., Onishi, H and Ruiz- Berraquero, M., 1989. Bacillus halophilus sp. nov., a moderately halophilic Bacillus species. Systematic and Applied Microbiology. 12: 162-16

Vessey, J.K., 2003. Plant growth promoting rhizobacteria as biofertilizers. Plant and Soil.

255: 571-586.

Voisard, C, Keel, C, Haas, D and Defago, G., 1989. Cyanide production by Pseudomonas fluorescens helps suppress black root rot of tobacco under gnotobiotic conditions. EMBO Journal. 8: 351-358.

Voisard, C., Bull, C. T., Keel, C., Laville, J., Maurhofer, M., Schnider, U., De! fago, G and Haas, D., 1994. Biocontrol of root diseases by Pseudomonas fuorescens CHA0: current concepts and experimental approaches. In Molecular Ecology of 
Rhizosphere Microorganisms. 67-89.

Voisard, C., Keel, C., Haas, D and De! fago, G., 1989. Cyanide production by Pseudomonas fuorescens helps suppress black root rot of tobacco under gnotobiotic conditions. EMBO Journal. 8: 351-358.

Walker, G.E., 1994. First report of Macrophomina phaseolina Associated with Vine Decline of Muskmelon in South Australia. Plant Disease. 78: 640.

Walker, R, Powell, A.A and Seddon, B., 1998. Bacillus isolates from the spermosphere of peas and dwarf French beans with antifungal activity against Botrytis cinerea and Pythium species. Journal of Applied Microbiology. 84: 791-801.

Walsh, U.F., Morrisey, J.P and O’Gara, F., 2001. Pseudomonas for biocontrol of phytopathogens: from functional genomics to commercial exploitation. Current Opinion in Biotechnology. 12: 289-295.

Wan, M, Li, G., Zhang, J., Jiang, D and Huang, H.C., 2008. Effect of volatile substances of Streptomyces platensis F-1 on control of plant fungal diseases. Biological Control. 46: 552-559.

Yasari, E and Patwardhan, A.M., 2007. Effects of Aztobacter and Azospirillium inoculations and chemical fertilizers on growth and productivity of Canola. Asian Journal of Plant Sciences. 77-82.
Yorinori., J.T., 1984. Fungal Diseases.Tropical soyabean: improvement an production. Embrapa (Eds). 37-60

Young, C.C., 1994. Selection and application of biofertilizers in Taiwan. Food and Fertilizer Technology Center. 141: 1-9.

Young, C.C., Chang, C.H., Chen, L.F and Chao, C.C., 1998. Characterization of the nitrogen fixing and ferric phosphate solubilizing bacteria isolated from Taiwan soil. Journal of the Chinese Agricultural Chemical Society. 36: 201-210.

Yu, G.Y, Sinclair, J.B., Hartman, G.L and Bertagnolli, B.L., 2002. Production of iturin A by Bacillus amyloliquefaciens suppresing Rhizoctonia solani. Soil Biology and Biochemistry. 34: 955-963.

Zahir, A.Z, Arshad, $\mathrm{M}$ and Fraankenberger, W.T., 2004. Plant growth promoting rhizobacteria: application and perspectives in Agriculture. Advance Agronomy. 81: 97168.

Zhang, X.P., Karsisto, M., Harper, R and Lindstrom, K., 1991. Diversity of Rhizobium bacteria isolated from the root nodules of leguminous trees. International Journal of Systametic Bacteriology. 41: 104-113.

\section{How to cite this article:}

Sureshbabu, K., N. Amaresan and Kumar, K. 2016. Amazing Multiple Function Properties of Plant Growth Promoting Rhizobacteria in the Rhizosphere Soil. Int.J.Curr.Microbiol.App.Sci.5(2): 661-683. doi: http://dx.doi.org/10.20546/ijcmas.2016.502.074 